\title{
PENGEMBANGAN MODEL PEMBELAJARAN IPA BERBASIS 4N (NENG, NING, NUNG, NANG) UNTUK MENCIPTAKAN PROSES BELAJAR FUNGSIONAL PESERTA DIDIK SMP
}

\author{
Ainun Fuadah ${ }^{1)}$, Djohar ${ }^{2)}$ \\ Sanggar Kegiatan Belajar Jombang Jawa Timur ${ }^{1)}$, Universitas Negeri Yogyakarta ${ }^{2)}$ \\ fuadah.ai@gmail.com ${ }^{1)}$, journal.pps@uny.ac.id ${ }^{2)}$
}

\begin{abstract}
Abstrak
Penelitian ini bertujuan untuk: (1) mengembangkan konsep 4N Ki Hajar Dewantara menjadi model pembelajaran $4 \mathrm{~N}$ dalam pembelajaran IPA, (2) mengetahui kualitas produk yang dikembangkan, (3) mengetahui pengaruh model pembelajaran 4N terhadap kompetensi Tri Nga, serta (4) mengetahui keterlaksanaan model pembelajaran IPA berbasis $4 \mathrm{~N}$. Penelitian pengembangan ini menggunakan 9 langkah model R\&D dari Borg \& Gall tanpa melalui tahap diseminasi. Hasil penelitian menunjukan bahwa: (1) Konsep 4N dapat dikembangkan menjadi model pembelajaran 4N, (2) Produk penelitian layak untuk digunakan dalam pembelajaran, (3) Model pembelajaran 4N berhasil menciptakan proses belajar IPA fungsional, karena (a) Model pembelajaran $4 \mathrm{~N}$ berhasil meningkatkan kompetensi Tri Nga, (b) pembelajaran IPA mencapai ketuntasan belajar, serta (c) model pembelajaran 4N mendapatkan respon baik dari peserta didik. (4) Model pembelajaran 4N dalam pembelajaran IPA terlaksana dengan baik.
\end{abstract}

Kata kunci: model pembelajaran, konsep 4N (neng-ning-nung-nang), belajar fungsional

\section{DEVELOPMENT OF SCIENCE LEARNING MODEL BASED ON 4N (NENG, NING, NUNG, NANG) CONCEPT TO ACHIEVE FUNCTIONAL LEARNING FOR THE STUDENTS OF JUNIOR HIGH SCHOOL}

\begin{abstract}
The aims of this study are (1) to develop $4 N$ concept from Ki Hajar Dewantara into $4 N$ model of learning for science, (2) to investigate the quality of developed products, (3) to investigate the effect of $4 \mathrm{~N}$ learning model for scinece learning to Tri Nga competencies, and (4) to investigate the implementation of the model.The study used 9 steps of research and development $(R \& D)$ model of Borg \& Gall without taking the dissemination process. The results of the study are as follows. (1) The $4 N$ concept was developed to become $4 N$ model for science learning. (2) The Products are appropriate to use for teaching and learning process. (3) The $4 N$ learning model can achieve a functional science learning: (a) the model can increase Tri Nga competencies. (b) Science learning using the $4 N$ model achieves the KKM target, and (c) the $4 N$ model gets good response from the students. (4) The $4 N$ model is in well done category.
\end{abstract}

Key words: learning model, $4 N$ (neng-ning-nung-nang) concept, functional learning. 


\section{PENDAHULUAN}

Peran sosial pendidikan di antaranya memungkinkan rakyat untuk mempertahankan kedaulatan serta menjadikan kekuasaan mereka efisien dan memuaskan (Thut \& Adams, 2005, p.22). Tujuan akademik pendidikan sains tidak dapat terlepas dari tujuan pendidikan secara holistik, yakni proses untuk mengembangkan manusia yang utuh yaitu manusia yang bermoral tinggi, bersikap dan berperilaku baik, serta memiliki kemampuan kognitif dan ketrampilan yang memadahi.

Pendidikan sains mempelajari alam semesta serta segala proses yang terjadi di dalamnya sebagai objeknya (Tim Pengembang Ilmu Pendidikan FIP-UPI, 200, p.187). Pendidikan sains bertujuan mendorong peserta didik untuk memahami proses dan produk sains, nilai sains, memiliki sikap ilmiah, mampu menjadi warga negara yang bermoral serta mempunyai kepekaan terhadap masalah lingkungan.

Secara lebih lengkap, tujuan pendidikan sains dapat dituliskan bahwa selain untuk memahami konsep IPA dan keterkaitannya, juga ditujukan untuk: (a) Meningkatkan kesadaran akan kelestarian lingkungan, kebanggaan nasional dan kebesaran Tuhan, (b) Mengem-bangkan daya penalaran untuk memecahkan masalah sehari-hari, (c) Mengembangkan ketrampilan proses untuk memperoleh konsep IPA dan menumbuhkan nilai serta sikap ilmiah, serta (d) Menerapkan konsep dan prinsip IPA untuk menghasilkan karya berupa teknologi.

Suparno (2007, p.1) mengemukakan dua kritik terhadap pendidik IPA, yakni (a) kurang menguasai materi fisika ,dan (b) kurang mampu mengajarkan materi itu kepada peserta didik dengan tepat, menarik dan efektif. Lemahnya kompetensi profesional pendidik mengakibatkan peserta didik tidak mampu memahami IPA, sehingga menyebabkan IPA menjadi pelajaran yang sulit. Selain itu lemahnya kompetensi pendidik mengakibatkan peserta didik tidak mempunyai pengalaman belajar yang bermakna karena proses belajar tidak fungsional bagi peserta didik dan peserta didik tidak mendapatkan pengetahuan baru. Mata pelajaran IPA tidak dapat mengembangkan kemampuan peserta didik untuk berpikir kritis, analitis dan sistematis, karena pendidik tidak memilih model pembelajaran yang mengkonstruksi pemahaman peserta didik dan mendorong peserta didik untuk berpikir kritis serta tidak mempertimbangkan kesesuaian model pembelajaran yang digunakan dengan kondisi nyata di kelas.

Banyak pendidik masih memakai model pembelajaran yang berpusat pada pendidik. Model ini kurang mendorong peserta didik untuk mengembangkan kemampuan berpikir dan memecahkan masalah serta kemampuan untuk mengaplikasikan pengetahuannya dalam kehidupan sehari-hari. Selain itu, seringkali pembelajaran IPA dilakukan dengan cara menghafal. Cara ini mengakibatkan peserta didik tidak mencapai pemahaman konsep IPA yang sesungguhnya.

Pembelajaran IPA yang ideal dilakukan dengan berorientasi faktual, kontekstual dan konseptual, yakni pembelajaran IPA yang fungsional. Sumber kajian IPA berupa alam. Oleh karena itu, seharusnya kegiatan pembelajaran IPA diarahkan sebagai pembelajaran yang mempelajari alam, bukan hanya mempelajari buku dengan menghafal rumus dan konsep saja.

Selama ini kegiatan pembelajaran IPA yang dilakukan kurang peduli terhadap proses, akan tetapi lebih perhatian terhadap produk belajar yakni pengetahuan IPA yang bersifat informatif. Untuk mencapai maksud itu, pembelajaran IPA secara sadar maupun tidak, telah diarahkan pada aktivitas hanya membaca buku atau rangkuman rumus singkat yang bersifat instan yang dianggap lebih efektif. Pendidik menjadi terbiasa menggunakan pendekatan tekstual yang bersifat instant dalam membelajarkan pengetahuan pada peserta didik, dan menjauhkan dari pendekatan kontekstual dan konseptual yang menggunakan objek dan persoalan nyata dalam belajar yang memerlukan kajian lebih lama tetapi realistik, meskipun bidang yang dipelajari merupakan bidang ilmu yang nyata seperti IPA.

Banyak komponen yang harus diperbaharui untuk menciptakan pembelajaran fungsional yang berbasis konstruktivis. Bagi beberapa pendidik, langkah ini dianggap merepotkan, karena pendidik harus melakukan banyak koreksi terhadap proses pembelajaran yang selama ini dilakukannya dan membuat perubahan yang lebih baik untuk meningkatkan mutu pembelajaran IPA. Oleh karena itu, banyak pendidik yang enggan mengubah model pembelajaran konvensional mereka yang sederhana, walaupun perubahan tersebut sangat diperlukan untuk membantu peserta didik dalam mencapai tujuan pembelajaran. Dalam pembelajaran IPA untuk aspek fisika perlu diupayakan untuk membantu peserta didik dalam belajar. Mereka perlu dimasukkan 
dalam situasi yang memaksa harus mengembangkan pengetahuan fisika, seperti museum fisika, laboratorium fisika, produk fisika, serta permainan yang menggunakan prinsip fisika (Suparno, 2007, pp.14-15).

Selama ini pendidikan terutama di sekolah telah banyak menerapkan berbagai sistem dan metode pendidikan dan pembelajaran yang berasal dari negara barat. Sistem yang diterapkan dapat berhasil, namun tidak sedikit pula yang tidak sesuai dengan nilai dan budaya bangsa Indonesia atau bahkan bertentangan, sehingga sistem tersebut tidak memberikan hasil seperti yang diharapkan. Dengan demikian, praktik pendidikan masih dianggap kurang memuaskan baik di luar negeri, seperti Amerika Serikat. Berdasarkan perspektif ini perlu dicari model pembelajaran yang sesuai dengan kebutuhan dan kebudayaan Indonesia yang lebih bersifat kontektual.

Sementara itu, masyarakat Indonesia masih banyak yang belum memahami bahwa bangsa Indonesia mempunyai sistem dan metode pembelajaran asli Indonesia yang diciptakan oleh putra Indonesia yang disebut dengan Sistem Among yang merupakan gagasan dari $\mathrm{Ki}$ Hajar Dewantara yang telah diterapkan melalui pendidikan Taman Siswa. Sistem Among merupakan gagasan otentik yang digali dari kearifan lokal. Sistem ini dapat manjadi unggulan dalam pendidikan di Indonesia dalam menghadapi persaingan pendidikan antarnegara, bahkan dapat menjadi unggulan dalam menghadapi persaingan global dalam dunia pendidikan.

Sayangnya belum ada penelitian lebih lanjut tentang pemikiran anak bangsa termasuk konsep Neng-Ning-Nung-Nang yang diajukan oleh Ki Hajar Dewantara yang dikembangkan menjadi model pembelajaran IPA. Selain itu belum tersedianya perangkat pembelajaran IPA SMP yang berbasis model pembelajaran 4N yang dikembangkan untuk menciptakan proses belajar fungsional.

Berdasarkan fokus permasalahan tersebut, penelitian ini dilakukan dengan tujuan untuk mengembangkan konsep 4N (Neng-Ning-NungNang) Ki Hajar Dewantara menjadi model pembelajaran IPA berbasis $4 \mathrm{~N}$ dalam pembelajaran IPA SMP. Selain itu juga berupaya untuk mengetahui kelayakan dan kualitas model $4 \mathrm{~N}$ yang berupa produk RPP, LKS pembelajaran IPA dan tes pilihan ganda berbasis $4 \mathrm{~N}$ dalam pembelajaran IPA yang dikembangkan. Penelitian ini juga ingin mengetahui pengaruh model pembelajaran IPA berbasis $4 \mathrm{~N}$ untuk menciptakan proses belajar IPA fungsional, serta mengetahui keterlak- sanaan model pembelajaran IPA berbasis $4 \mathrm{~N}$ yang dikembangkan.

Spesifikasi produk yang dikembangkan melalui penelitian ini berupa model pembelajaran berbasis $4 \mathrm{~N}$ yang dikembangkan dari konsep 4N Ki Hajar Dewantara yang dikemas dalam panduan model pembelajaran $4 \mathrm{~N}$ yang meliputi konsep kemerdekaan Ki Hajar Dewantara, sintaks model, sistem sosial, prinsip reaksi, sistem pendukung, dampak instruksional, serta dampak pengiringnya. Pengembangan model pembelajaran berbasis $4 \mathrm{~N}$ dituangkan dalam bentuk silabus, RPP, lembar kegiatan peserta didik IPA berbasis $4 \mathrm{~N}$, dan instrumen evaluasi hasil belajar yang berupa soal pilihan ganda berbasis $4 \mathrm{~N}$.

Hasil penelitian ini diharapkan dapat memperkaya khazanah keilmuan tentang model pembelajaran yang bisa digunakan untuk pembelajaran IPA dalam rangka meningkatkan kompetensi peserta didik SMP serta menjadi motivasi dan referensi bagi penelitian lain yang bertujuan untuk meningkatkan mutu pembelajaran IPA. Model pembelajaran 4N ini bisa dipakai oleh pendidik untuk membangun pembelajaran IPA yang konstruktivistik dan menyenangkan.

Asumsi pengembangan dalam penelitian ini adalah bahwa konsep 4N dari Ki Hajar Dewantara ini bisa dikembangkan sebagai model pembelajaran IPA dan dapat diwujudkan dalam bentuk perangkat pembelajaran untuk menciptakan proses belajar fungsional. Keterbatasan penelitian ini di antaranya (1) dilaksanakan sesuai dengan tahapan model penelitian pengembangan Borg \& Gall mulai research and information collecting sampai tahap operational product revision saja, (2) tidak dilakukan diseminasi, walaupun telah diujicobakan pada sampel yang meliputi peserta didik SMP kelas VIII, serta (3) perangkat pembelajaran IPA berbasis model pembelajaran $4 \mathrm{~N}$ dibuat untuk materi tekanan saja.

Beberapa istilah yang perlu dijelaskan, di antaranya (a) metode penelitian dan pengembangan yang merupakan metode penelitian yang digunakan untuk menghasilkan produk tertentu dan menguji keefektifan produk tersebut (Sugiyono. 2010, p.407). (b) model pembelajaran berbasis $4 \mathrm{~N}$ merupakan model pembelajaran yang dikembangkan dari konsep pemikiran $\mathrm{Ki}$ Hajar Dewantara Neng-Ning-Nung-Nang yang menggambarkan tentang konsep belajar orang merdeka yang memberikan kesempatan yang luas kepada peserta didik untuk mempelajari IPA dengan berinteraksi langsung dengan objek belajar, berpikir kritis dan analitis dalam meng- 
hadapi masalah IPA yang dihadapinya, serta menerapkannya dalam kehidupan sehari-hari. (c) Proses Belajar IPA yang fungsional merupakan proses belajar IPA yang efektif dan memberi pengalaman belajar yang sesungguhnya bagi peserta didik. Proses belajar fungsional mempunyai tiga kriteria, yakni (1) tercapainya kompetensi peserta didik dalam pembelajaran IPA berbasis model 4N, (2) pencapaian ketuntasan belajar peserta didik yang dilihat secara klasikal berdasarkan nilai KKM sekolah, serta (3) pembelajaran yang dilakukan merupakan pembelajaran yang menyenangkan bagi peserta didik.

\section{METODE}

\section{Jenis Penelitian}

Penelitian ini termasuk dalam klasifikasi penelitian pengembangan. Produk yang dikembangkan dalam penelitian ini berupa model pembelajaran IPA berbasis 4N. Penelitian pengembangan ini menggunakan sembilan langkah penelitian pengembangan menurut Borg \& Gall.

\section{Waktu dan Tempat Penelitian}

Penelitian ini dilaksanakan pada bulan Januari-Juli 2013 bertempat di SMP Negeri 3 Banguntapan Bantul.

\section{Subjek Penelitian}

Subjek penelitian untuk uji coba produk yang dikembangkan dalam penelitian ini merupakan peserta didik SMP. Subjek uji coba perseorangan terdiri dari tiga orang peserta didik SMP yang dipilih secara random. Subjek uji coba lapangan utama terbatas sebanyak sepuluh orang peserta didik SMP kelas VIII. Subjek uji coba lapangan operasional terdiri dari peserta didik kelas VIIIA dan VIIIC SMPN 3 Banguntapan Bantul yang dipilih dengan teknik purposive random sampling sebagai kelas kontrol dan kelas eksperimen.

Objek uji coba penelitian ini berupa buku panduan model, perangkat pembelajaran dan instrumen yang digunakan dalam penelitian.

\section{Prosedur Pengembangan}

Prosedur pengembangan mengikuti tahapan dari Borg \& Gall, yakni (1) research and information collecting; melakukan penelitian pendahuluan dan pengumpulan informasi (kajian pustaka, observasi atau pengamatan kelas, analisis kebutuhan, persiapan laporan tentang pokok persoalan), (2) planning; melakukan perencanaan (menentukan prosedur pengembangan, metode pembelajaran dan prosedur pengembangan produk), (3) develop preliminary form of product; mengembangkan bentuk produk awal (penyiapan materi dan produk awal, perlengkapan evaluasi, validasi para ahli dan revisi produk awal). (4) preliminary field testing; melakukan uji coba perseorangan (10 subjek). Data angket dikumpulkan dan dianalisis sebagai dasar revisi pertama. (5) main product revision; melakukan revisi pertama terhadap produk (sesuai dengan data yang sudah dianalisis dari hasil uji coba perseorangan),(6) main field testing; melakukan uji coba kelompok kecil. Data dikumpulkan dan dianalisis sebagai dasar revisi kedua. (7) operational product revision; melakukan revisi kedua terhadap produk (sesuai dengan data yang sudah dianalisis dari hasil uji coba kelompok kecil). (8) operational field testing; melakukan uji coba lapangan (64 subjek) dalam 2 kelas. Data angket dikumpulkan dan analisis sebagai dasar revisi ketiga. (9) final product revision; melakukan revisi terhadap produk akhir berdasarkan masukan yang diperoleh dari uji lapangan operasional.

\section{Data, Instrumen, dan Teknik Pengumpulan Data}

Data yang diperoleh terdiri dari 2 macam, yakni (a) data pimer, yaitu data tentang kelayakan pengembangan model pembelajaran IPA berbasis 4N. Data yang dikumpulkan berupa hasil validasi para ahli, pendidik, dan teman sejawat, termasuk tanggapan, masukan dan kritikan. Data tersebut meliputi skor penilaian dari aspek kelayakan isi, aspek kebahasaan, aspek penyajian dan aspek kegrafikaan. (b) Data sekunder diperoleh dari kegiatan pembelajaran. Data tersebut meliputi data keterlaksanaan dan kompetensi peserta didik setelah mengikuti pembelajaran IPA menggunakan model pembelajaran 4N dan keterlaksanaannya. Data hasil pretest dan posttest baik dari kelas kontrol maupun kelas eksperimen untuk mengetahui perbedaan hasil belajar peserta didik yang menerapkan pembelajaran IPA dengan model pembelajaran berbasis $4 \mathrm{~N}$, serta skor afeksi dan psikomotorik peserta didik yang tergabung dalam kompetensi tri "Nga".

Instrumen pengumpulan data yang digunakan, meliputi (a) instrumen validasi, (b) instrumen tes hasil belajar yakni pretest dan posttest, (c) lembar observasi, (d) angket tanggapan peserta didik terhadap model pem- 
belajaran $4 \mathrm{~N}$ dan perangkat pembelajaran IPA berbasis $4 \mathrm{~N}$, serta (e) dokumentasi.

\section{Teknik Analisis Data}

Untuk menganalisis kelayakan produk digunakan analisis deskriptif kuantitatif. Proses analisa data yang dilakukan meliputi (1) analisis kelayakan produk, (2) validasi dan pengukuran reabilitas butir soal, (3) homogenitalis data, (4) normalitas data, (5) skor hasil pretest dan post test, (6) keterlaksanaan pembelajaran, dan (7) respon peserta didik.

Analisa kelayakan produk dengan menggunakan 4 kriteria. Kriteria tersebut dicari dengan rumus:

\section{Skor terting gi-Skor terendah \\ Jumlah Kelas Interval}

Kriteria penilaian kelayakan model pembelajaran 4N disajikan dalam Tabel 1.

Tabel 1. Kriteria Penilaian Model Pembelajaran IPA Berbasis 4N

\begin{tabular}{llc}
\hline No & \multicolumn{1}{c}{ Skor } & Kategori \\
\hline 1 & $88.2<x \leq 105$ & Sangat baik \\
2 & $71.4<x \leq 88.2$ & Baik \\
3 & $54.6<x \leq 71.4$ & Cukup baik \\
4 & $37.8<x \leq 54.6$ & Tidak baik \\
5 & $21 \leq x \leq 37.8$ & Sangat tidak baik \\
\hline
\end{tabular}

Untuk kriteria penilaian kelayakan RPP IPA berbasis model pembelajaran $4 \mathrm{~N}$ disajikan pada Tabel 2.

Tabel 2. Kriteria penilaian RPP IPA berbasis 4N

\begin{tabular}{ccc}
\hline No & Skor & Kategori \\
\hline 1 & $109.2<x \leq 130$ & Sangat baik \\
2 & $88.4<x \leq 109.2$ & Baik \\
3 & $67.6<x \leq 88.4$ & Cukup baik \\
4 & $46.8<x \leq 67.6$ & Tidak baik \\
5 & $26 \leq x \leq 46.8$ & Sangat tidak baik \\
\hline
\end{tabular}

Kriteria penilaian kelayakan LKS IPA berbasis model pembelajaran $4 \mathrm{~N}$ disajikan dalam Tabel 3.

Tabel 3. Kriteria penilaian LKS IPA berbasis 4N

\begin{tabular}{ccc}
\hline No & Skor & Kategori \\
\hline 1 & $142.8<x \leq 170$ & Sangat baik \\
2 & $115.2<x \leq 142.8$ & Baik \\
3 & $88.4<x \leq 115.6$ & Cukup baik \\
4 & $61.2<x \leq 88.4$ & Tidak baik \\
5 & $34 \leq x \leq 61.2$ & Sangat tidak baik \\
\hline
\end{tabular}

Penilaian kelayakan tes pilihan ganda berbasis model pembelajaran $4 \mathrm{~N}$ tidak menggunakan kriteria seperti di atas akan tetapi dengan validasi isi oleh ahli materi IPA.
Uji homogenitas dan reliabilitas data dilakukan dengan menggunakan bantuan program SPSS 18 untuk menguji hasil pretest yang diperoleh dari kelompok sampel. Data yang didapatkan dari posttest digunakan untuk mengetahui ada atau tidaknya peningkatan kompetensi peserta didik setelah adanya perlakuan model $4 \mathrm{~N}$ serta besarnya pengaruh model pembelajara $4 \mathrm{~N}$ terhadap kompetensi Tri-Nga peserta didik.

Data yang didapatkan ini juga dianalisis memakai uji t dengan bantuan program SPSS. Analisis keterlaksanaan model pembelajaran 4N dan ketercapaian ketuntasan belajar peserta didik berdasarkan KKM, ditentukan oleh sekolah yang dihitung berdasarkan presentasinya dengan menggunakan rumus sebagai berikut:

$$
N_{K}=\left(\frac{N_{A}}{N_{T}}\right) x 100 \%
$$

Analisa pencapaian kompetensi ngrasa dalam pembelajaran IPA berbasis $4 \mathrm{~N}$ diukur dengan menggunakan kriteria yang disajikan pada Tabel 4.

Tabel 4. Kriteria penilaian kompetensi ngrasa

\begin{tabular}{ccc}
\hline No & Skor & Kategori \\
\hline 1 & $16,5<x \leq 22$ & Sangat Tercapai \\
2 & $11<x \leq 16,5$ & Tercapai \\
3 & $5,5<x \leq 11$ & Kurang Tercapai \\
4 & $0 \leq x \leq 5,50$ & Sangat Kurang Tercapai \\
\hline
\end{tabular}

Pencapaian kompetensi nglakoni diukur dengan menggunakan kriteria pada Tabel 5.

Tabel 5. Kriteria penilaian kompetensi nglakoni

\begin{tabular}{ccc}
\hline No & Skor & Kategori \\
\hline 1 & $6.0<x \leq 8.0$ & Sangat Tercapai \\
2 & $4.0<x \leq 6.0$ & Tercapai \\
3 & $2.0<x \leq 4.0$ & Kurang Tercapai \\
4 & $0 \leq x \leq 2.0$ & Sangat Kurang Tercapai \\
\hline
\end{tabular}

Respon peserta didik terhadap model pembelajaran 4N dan LKS IPA didapatkan dari angket yang dianalisis dengan kriteria sesuai pada Tabel 6 .

Tabel 6. Kriteria respon peserta didik

\begin{tabular}{ccc}
\hline No & Skor & Kategori \\
\hline 1 & $84<x \leq 100$ & Sangat baik \\
2 & $68<x \leq 84$ & Baik \\
3 & $52<x \leq 68$ & Cukup baik \\
4 & $36<x \leq 52$ & Tidak baik \\
5 & $20 \leq x \leq 36$ & Sangat tidak baik \\
\hline
\end{tabular}




\section{HASIL DAN PEMBAHASAN}

Hasil penelitian dan pembahasan dalam penelitian ini, dituliskan berdasarkan urutan langkah pengembangan dari model Borg \& Gall. Tahap penelitian pendahuluan dilakukan untuk mengetahui kebutuhan peserta didik dan pendidik tentang materi atau pokok bahasan dalam mata pelajaran sains, sehingga dapat diketahui kualitas praktek pembelajaran IPA di kelas. Selain itu identifikasi masalah dalam pembelajaran, antara lain (a) murid masih memakai buku sebagai sumber belajar yang utama dalam belajar IPA yang seharusnya pembelajaran IPA bersumber dari alam dan peserta didik berinteraksi sedekat mungkin dengan alam sebagai sumber yang dipelajari. (b) proses pembelajaran dilakukan dengan memakai buku dan lembar kerja peserta didik yang kurang representatif, karena hanya dipakai untuk penugasan di rumah saja, belum bisa dijadikan sebagai pegangan aktivitas peserta didik dalam mempelajari IPA di kelas. (c) praktikum pembelajaran dan materi pembelajaran seringkali dianggap menjadi hal yang berbeda. Seharusnya pembelajaran IPA berbasis praktek dan materi merupakan pelengkap pembelajaran yang digunakan secara bersamaan di dalam kelas.

Selain itu juga ditemukan referensi tentang ajaran dan pemikiran Ki Hajar Dewantara dan informasi tentang SK dan KD untuk materi yang belum diajarkan yang disajikan pada Tabel 7.

Tabel 7. Hasil Studi Kurikulum di Sekolah; SK dan KD IPA kelas VIII

\begin{tabular}{ll}
\hline \multicolumn{1}{c}{ Standar Kompetensi } & \multicolumn{1}{c}{ Kompetensi Dasar } \\
\hline 5. Memahami peranan & $\begin{array}{l}\text { 5.5. Menyelidiki tekanan } \\
\text { usaha, gaya, dan energi } \\
\text { pada benda padat, cair, dan } \\
\text { dalam kehidupan }\end{array}$ \\
$\begin{array}{l}\text { gas serta penerapannya } \\
\text { dalam kehidupan sehari- } \\
\text { hari }\end{array}$ \\
\hline
\end{tabular}

Tahap perencanaan produk terdiri dari tahapan, di antaranya (a) perumusan komponen model yang akan dikembangkan, (b) perumusan tujuan pembelajaran, (c) perumusan butir materi pembelajaran, (d) penentuann urutan pembelajaran yang termuat dalam kisi-kisi RPP, (e) merumuskan isi lembar kerja peserta didik, (f) mengembangkan alat ukur ketercapaian dan keberhasilan dalam pembelajaran dan penelitian, serta $(\mathrm{g})$ perancangan instrumen untuk uji kelayakan produk.

Tahap pengembangan produk yang berupa menyusun sebanyak 4 produk, yakni panduan model 4N untuk pembelajaran, RPP, LKS untuk peserta didik dan pendidik, serta tes pilihan ganda. Pada tahap ini dilakukan empat langkah, yakni (a) membuat desain awal model pembelajaran 4N, (b) membuat desain komponen proses pembelajaran dengan model $4 \mathrm{~N}$ yang terdiri dari perencanaan, pelaksanaan dan penilaian hasil pembelajaran. Dalam perencanaan pembelajaran, yang dikembangkan berupa silabus dan RPP yang sesuai dengan model 4N. Untuk mendukung pelaksanaan pembelajaran yang dikembangkan berupa desain kegiatan awal, inti dan pembelajaran, sedangkan dalam penilaian pembelajaran meliputi pengembangan desain instrumen penilaian hasil pembelajaran yang berupa tes dan nontes yang dilakukan melalui kuis dan ulangan harian. Pelaporan hasil pembelajaran terdiri dari konversi skor dan penyajiannya. (c) penyusunan kerangka isi LKS berbasis $4 \mathrm{~N}$ yang terdiri dari daftar isi, peta konsep materi, SK-KD dan tujuan pembelajaran, tahapan belajar $4 \mathrm{~N}$ dan tes pemahaman materi. (d) instrumen tes pilihan ganda untuk mengetahui pencapaian kompetensi ngarti peserta didik. Tes ini dibuat berdasarkan konsep model $4 \mathrm{~N}$ yang memfokuskan pada pembelajaran ketrampilan proses, tujuan pembelajaran serta tingkat pencapaian kognitif peserta didik yang direncanakan, yakni tingkat pengetahuan kognitif pada tingkat C4.

Setelah empat produk dikembangkan, langkah selanjutnya adalah meminta pendapat kepada ahli, teman sejawat dan pendidik IPA SMP tentang kualitas produk yang dikembangkan. Ahli yang diminta untuk menilai kualitas dan memberikan masukan terhadap produk sebanyak 3 orang yang masing-masing mempunyai keahlian tentang kualitas materi, media dan konsep 4N. Teman sejawat terdiri dari 2 orang dan 1 pendidik IPA SMP. Hasil penilaian terhadap panduan model pembelajaran IPA berbais 4N disajikan dalam Tabel 7.

Tabel 8. Hasil penilaian ahli, teman sejawat dan pendidik IPA terhadap panduan model pembelajaran IPA berbasis $4 \mathrm{~N}$

\begin{tabular}{ccc}
\hline Penilai & $\begin{array}{c}\text { Sub } \\
\text { Total }\end{array}$ & Kategori \\
\hline Ahli Materi, Konsep 4N dan & 120 & Sangat baik \\
Media & 111,5 & Sangat Baik \\
Teman Sejawat & 118 & Sangat baik \\
Pendidik IPA SMP & 349,5 & \\
Skor Total & 116,5 & Sangat \\
Rerata & & Baik \\
\hline
\end{tabular}


Hasil penilaian yang ditunjukkan dalam Tabel 8 menggambarkan bahwa model pembelajaran IPA berbasis $4 \mathrm{~N}$ yang dikembangkan mempunyai kualitas sangat baik dan layak digunakan dalam pembelajaran IPA pada tingkat SLTP.

Tabel 9. Hasil Penilaian Ahli, Teman Sejawat dan Pendidik IPA Terhadap RPP IPA

\begin{tabular}{|c|c|c|}
\hline Penilai & $\begin{array}{l}\text { Sub } \\
\text { Total }\end{array}$ & Kategori \\
\hline $\begin{array}{c}\text { Ahli Materi, Konsep 4N } \\
\text { dan Media }\end{array}$ & 120 & $\begin{array}{l}\text { Sangat } \\
\text { baik }\end{array}$ \\
\hline Teman Sejawat & 111,5 & $\begin{array}{l}\text { Sangat } \\
\text { Baik }\end{array}$ \\
\hline Pendidik IPA SMP & 118 & $\begin{array}{l}\text { Sangat } \\
\text { baik }\end{array}$ \\
\hline Skor Total & 349,5 & \\
\hline Rerata & 116,5 & $\begin{array}{l}\text { Sangat } \\
\text { Baik }\end{array}$ \\
\hline
\end{tabular}

Hasil penilaian terhadap RPP berbasis 4N yang ditunjukkan pada Tabel 9 menggambarkan bahwa RPP IPA berbasis 4N yang dikembangkan mempunyai kualitas sangat baik dan layak digunakan sebagai perangkat pembelajaran IPA pada tingkat SLTP. Selanjutnya, hasil penilaian terhadap LKS disajikan dalam Tabel 10.

Tabel 10. Hasil Penilaian Ahli, Teman Sejawat dan Pendidik IPA Terhadap LKS IPA berbasis $4 \mathrm{~N}$

\begin{tabular}{ccc}
\hline Penilai & $\begin{array}{c}\text { Sub } \\
\text { Total }\end{array}$ & Kategori \\
\hline Ahli Materi, Konsep 4N & 156 & Sangat baik \\
dan Media & & Sangat \\
Teman Sejawat & 149 & Baik \\
Pendidik IPA SMP & 152 & Sangat baik \\
Skor Total & $\mathbf{4 5 7}$ & \\
Rerata & $\mathbf{1 5 2 , 3}$ & Sangat Baik \\
\hline
\end{tabular}

Produk LKS IPA berbasis 4N yang dikembangkan juga mempunyai kualitas yang sangat baik, sehingga layak digunakan di dalam pembelajaran IPA sebagai alat bantu pembelajaran IPA berbasis $4 \mathrm{~N}$.

Masukan dari para ahli, pendidik SMP dan teman sejawat ini dijadikan landasan untuk melakukan revisi terhadap produk yang dikembangkan.

Tahap selanjutnya berupa tahap uji coba. Sebanyak tiga kali uji coba yang dilaksanakan, yakni uji coba perseorangan, uji coba kelompok terbatas dan uji coba kelompok operasional. Dalam uji coba perseorangan, model pembelajaran $4 \mathrm{~N}$ dalam pembelajaran IPA dan LKS IPA berbasis $4 \mathrm{~N}$ diberikan kepada 3 orang subyek uji coba yang dipilih dengan cara purposive random sampling dan terdiri dari peserta didik dengan tingkat prestasi IPA tinggi, sedang dan rendah. Adapun data respon peserta didik terhadap model pembelajaran IPA berbasis $4 \mathrm{~N}$ dan LKS IPA berbasis 4N disajikan di Tabel 11 .

Berdasarkan kategorisasi penilaian angket respon peserta didik terhadap model pembelajaran $4 \mathrm{~N}$, diperoleh kesimpulan bahwa model pembelajaran $4 \mathrm{~N}$ yang dipraktekkan di dalam kelas mendapatkan respon baik dari peserta didik.

Tabel 11. Hasil Skor Angket Peserta didik terhadap Model Pembelajaran 4N dalam Uji Perseorangan

\begin{tabular}{cc}
\hline Peserta didik & $\begin{array}{c}\text { Skor Respon terhadap Model } \\
\text { Pembelajaran 4N }\end{array}$ \\
\hline P1 & 87 \\
P2 & 74 \\
P3 & 82 \\
Total & 243 \\
Rerata & 81 \\
Kategori & Baik \\
\hline
\end{tabular}

Adapun respon peserta didik terhadap LKS IPA berbasis 4N disajikan dalam Tabel 12.

Tabel 12. Skor Angket Peserta didik terhadap LKS IPA berbasis $4 \mathrm{~N}$ dalam Uji Perseorangan

\begin{tabular}{cc}
\hline Peserta didik & $\begin{array}{c}\text { Skor Respon terhadap Model } \\
\text { Pembelajaran 4N }\end{array}$ \\
\hline P1 & 63 \\
P2 & 66 \\
P3 & 66 \\
Total & 195 \\
Rerata & 65 \\
Kategori & Sangat Baik \\
\hline
\end{tabular}

Berdasarkan kategorisasi penilaian angket respon peserta didik terhadap LKS IPA Berbasis Model Pembelajaran 4N, dapat disimpulkan bahwa LKS IPA Berbasis Model Pembelajaran $4 \mathrm{~N}$ yang dibagikan di dalam kelas uji perseorangan mendapatkan respon sangat baik.

Respon peserta didik terhadap model pembelajaran 4N dan LKS IPA berbasis model pembelajaran $4 \mathrm{~N}$ bisa dilihat pada Gambar 1. 


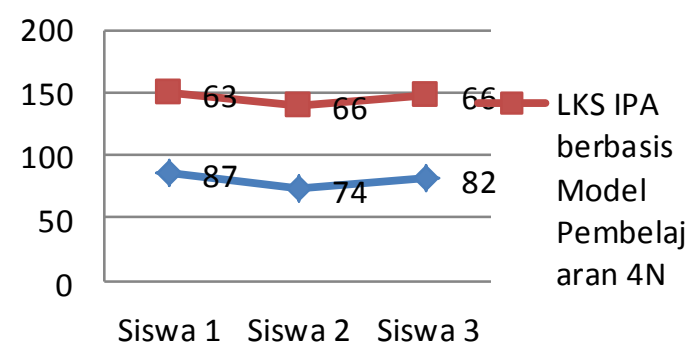

Gambar 1. Respon Peserta Didik di dalam Uji Perseorangan

Selain mendapatkan data yang berupa angka, dari uji perseorangan juga didapatkan masukan yang terkait dengan model pembelajaran $4 \mathrm{~N}$ dan LKS IPA berbasis 4N. Masukan ini kemudian dijadikan sebagai bahan untuk melakukan revisi agar produk dapat dipergunakan dalam uji coba kelompok terbatas.

Subjek uji coba kelompok terbatas terdiri dari 10 peserta didik yang dipilih secara acak oleh pendidik IPA. Adapun data yang diperoleh berupa respon peserta didik terhadap model pembelajaran $4 \mathrm{~N}$ dan LKS IPA berbasis $4 \mathrm{~N}$ seperti yang disajikan pada Tabel 13 .

Tabel 13. Respon Peserta didik terhadap Model

Pembelajaran $4 \mathrm{~N}$ pada Uji Coba Lapangan Terbatas

\begin{tabular}{cc}
\hline $\begin{array}{c}\text { Peserta Didik } \\
\text { Uji Terbatas }\end{array}$ & $\begin{array}{c}\text { Skor Respon terhadap Model } \\
\text { Pembelajaran 4N }\end{array}$ \\
\hline T1 & 98 \\
T2 & 94 \\
T3 & 96 \\
T4 & 78 \\
T5 & 91 \\
T6 & 96 \\
T7 & 96 \\
T8 & 89 \\
T9 & 87 \\
T10 & 94 \\
Total & 919 \\
Rerata & 91,9 \\
Kategori & Sangat Baik \\
\hline Keterati
\end{tabular}

Keterangan:

$\mathrm{T}=$ peserta uji kelompok terbatas (sebanyak 10 orang)

Berdasarkan kategorisasi penilaian respon peserta didik terhadap model pembelajaran $4 \mathrm{~N}$ diperoleh kesimpulan bahwa model pembelajaran 4N yang dipraktekkan di dalam kelas mendapatkan respon sangat baik dari peserta didik.

Rerata respon peserta didik terhadap model pembelajaran $4 \mathrm{~N}$ sebesar 68,8 . Berdasarkan kategori penilaian respon peserta didik terhadap
LKS IPA berbasis model pembelajaran 4N diperoleh hasil bahwa LKS yang dikembangkan pada uji coba lapangan terbatas mendapatkan respon sangat baik.

Tabel 14. Respon Peserta didik Terhadap LKS IPA Berbasis Model Pembelajaran 4N pada Uji

Coba Lapangan Terbatas

\begin{tabular}{cc}
\hline $\begin{array}{c}\text { Peserta } \\
\text { didik }\end{array}$ & Skor Respon terhadap LKS IPA \\
\hline T1 & 72 \\
T2 & 75 \\
T3 & 72 \\
T4 & 64 \\
T5 & 67 \\
T6 & 71 \\
T7 & 69 \\
T8 & 70 \\
T9 & 60 \\
T10 & 68 \\
Total & 688 \\
Rerata & 68.8 \\
Kategori & Sangat Baik \\
\hline
\end{tabular}

Respon peserta terhadap model pembelajaran $4 \mathrm{~N}$ dan LKS IPA berbasis model pembelajaran $4 \mathrm{~N}$ pada dalam uji coba lapangan dapat dilihat pada Gambar 2.

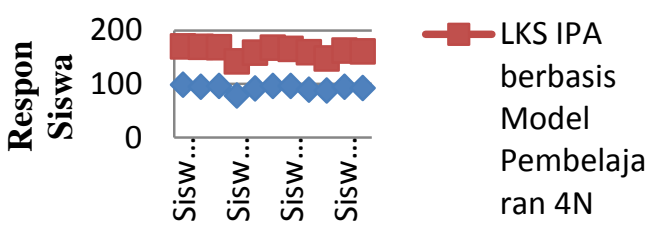

Gambar 2. Diagram Respon Peserta Didik pada

Uji Coba Terbatas Terhadap Model

Pembelajaran 4N dan LKS IPA berbasis 4N.

Seperti pada uji coba sebelumnya, diperoleh masukan dari peserta didik untuk melakukan perbaikan terhadap implementasi model 4N di dalam pembelajaran IPA dan LKS IPA berbasis $4 \mathrm{~N}$. Setelah dilakukan revisi, produk dianggap sudah layak untuk Pada uji coba kelompok besar ini metode yang digunakan adalah quasi eksperimen dengan 1 kelas kontrol dan 1 kelas eksperimen. Data yang diambil pada kelompok besar ini lebih banyak karena sesuai dengan variabel yang direncanakan dalam penelitian. Dalam uji coba ini, hasil yang ingin didapatkan berupa pengaruh penggunaan model pembelajaran IPA berbasis 4N terhadap kompetensi Tri nga peserta didik, respon peserta didik, keterlaksanaan model $4 \mathrm{~N}$ dalam pembelajaran IPA di sekolah, serta ketuntasan belajar peserta didik. 


\section{Keterlaksanaan Model 4N dalam Pembel- ajaran IPA}

Data mengenai keterlaksanaan model pembelajaran $4 \mathrm{~N}$ di dalam uji coba lapangan operasional dilakukan pada 4 kali pertemuan. Observer memberikan tanda ceklist untuk memberikan skor pada item yang dinilai.

Sebanyak lima komponen model yang dinilai yang meliputi keterlaksanaan sintaks model pembelajaran $4 \mathrm{~N}$, sistem sosial, prinsip reaksi, sistem pendukung serta dampak instruksional dan pengiring. Setiap komponen telah dinilai dan akumulasi penilaian masing-masing komponen menggambarkan hasil penilaian terhadap keterlaksanaan model pembelajaran $4 \mathrm{~N}$ selama pertemuan berlangsung.

Tabel 15. Data Keterlaksanaan Model Pembelajaran 4N

\begin{tabular}{cccc}
\hline No & Pertemuan & Skor & Kategori \\
\hline 1 & Pertama & 20 & Terlaksana \\
2 & Kedua & 21 & Terlaksana \\
3 & Ketiga & 25 & Sangat Terlaksana \\
4 & Keempat & 26 & Sangat Terlaksana \\
& Rata-rata & $\mathbf{2 3}$ & Sangat Terlaksana \\
\hline
\end{tabular}

Pada pertemuan pertama dan kedua, pendidik dan peserta didik masih menyesuaikan diri dengan model pembelajaran 4N. Oleh karena itu keterlaksanaan model pembelajaran $4 \mathrm{~N}$ pada pertemuan ketiga dan keempat lebih baik daripada pertemuan sebelumnya.

Rata-rata skor keterlaksaan selama 4 kali pertemuan sebesar 23 yang berarti bahwa pencapaian keterlaksanaan model pembelajaran di dalam kelas ini mencapai kategori sangat terlaksana. Tingkat keterlaksanaan model pembelajaran $4 \mathrm{~N}$ pada pembelajaran IPA dapat dilihat pada Gambar 3.

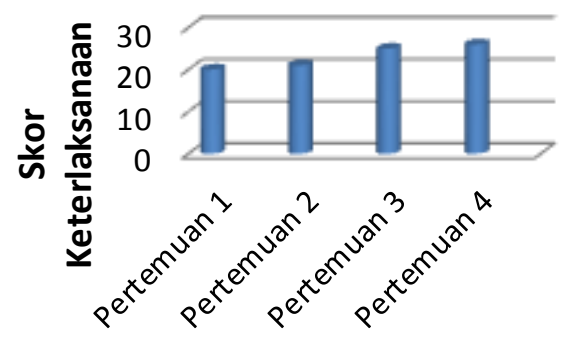

Gambar 3. Histogram Keterlaksanaan Model Pembelajaran 4N

\section{Pengaruh Model 4N terhadap Kompetensi Tri Nga}

Aktivitas pembelajaran IPA yang termuat dalam RPP disesuaikan dengan tujuan dan sistem sosial (aspek kompetensi Ngrasa dan Nglakoni) di dalam kelas yang diharapkan terbentuk dalam model pembelajaran $4 \mathrm{~N}$. Oleh karena itu, data yang dihasilkan merupakan data yang bisa dipakai untuk mengukur tingkat keterlibatan peserta didik dalam proses pembelajaran 4N, sekaligus mengukur kompetensi Ngrasa dan Nglakoni yang dicapai oleh peserta didik. Lembar observasi aktivitas peserta didik mempunyai 22 item yang diobservasi yang berhubungan dengan aspek Ngrasa serta 8 item yang berhubungan dengan aspek Nglakoni.

Tabel 16. Hasil Observasi Aktivitas Peserta didik pada Proses Pembelajaran 4N

\begin{tabular}{ccccc}
\hline & \multicolumn{4}{c}{ Jumlah Peserta didik } \\
\cline { 2 - 5 } Aspek & \multicolumn{4}{c}{ Kategori Ketercapaian } \\
\cline { 2 - 5 } & $\begin{array}{c}\text { Sangat } \\
\text { Kurang } \\
\text { Tercapai }\end{array}$ & $\begin{array}{c}\text { Kurang } \\
\text { Tercapai }\end{array}$ & Tercapai & $\begin{array}{c}\text { Sangat } \\
\text { Tercapai }\end{array}$ \\
\hline Ngrasa & 0 & 3 & 7 & 22 \\
Nglakoni & 0 & 1 & 11 & 20 \\
\hline
\end{tabular}

Berdasarkan Tabel 16 dapat dilihat bahwa kompetensi Ngrasa dicapai dengan kategori kurang tercapai oleh sebanyak 3 orang peserta didik $(9,4 \%)$, kategori tercapai diraih oleh 7 peserta didik $(21,9 \%)$ dan 22 orang lainnya 68,8\%) mencapai kompetensi Ngrasa dengan kategori sangat tercapai. Penyajian data tersebut dalam bentuk diagram lingkar seperti yang tercantum pada Gambar 4.

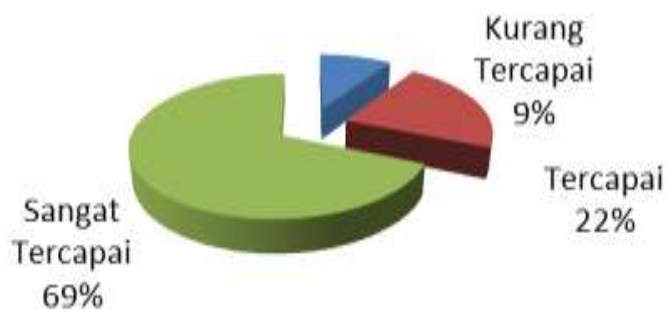

Gambar 4. Diagram Lingkaran Hasil Pencapaian Kompetensi Ngrasa

Sebanyak 1 orang peserta didik $(3,125 \%)$ dalam kelas mencapai kompetensi ngalakoni dengan kategori kurang tercapai, 11 orang peserta didik $(34,375 \%)$ mencapai kompetensi dengan kategori tercapai, sedangkan 2 peserta didik (67\%) mendapatkan skor dengan pencapaian kompetensi sangat tercapai. Penyajian data dalam bentuk diagram lingkaran dapat dilihat pada Gambar 5 . 


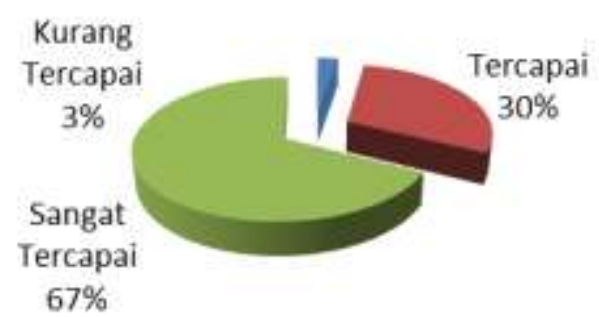

Gambar 5. Diagram Lingkaran Hasil Pencapaian Kompetensi Nglakoni

Berdasarkan Gambar 5 terlihat jelas bahwa kompetensi Ngrasa dan Nglakoni dalam proses pembelajaran IPA berbasisi $4 \mathrm{~N}$ memiliki peringkat sangat tercapai sesuai dengan maksud dan tujuan model pembelajaran $4 \mathrm{~N}$.

Pengaruh model pembelajaran $4 \mathrm{~N}$ dan perangkatnya terhadap kompetensi Ngarti, Ngrasa dan Nglakoni peserta didik dihitung dengan Uji regresi dengan bantuan program SPSS 18.

\section{Pengujian Hipotesis}

Hasil uji regresi untuk melihat pengaruh model pembelajaran $4 \mathrm{~N}$ terhadap kompetensi Ngarti disajikan dalam Tabel 16.

Tabel 17. Output Model Summary Uji Regresi Kompetensi Ngarti

\begin{tabular}{cccc}
\hline Model & R & R Square & Adjusted R Square \\
\hline 1 & 0,886 & 0,785 & 0,778 \\
\hline
\end{tabular}

Berdasarkan Tabel 17 diketahui bahwa korelasi antara respon peserta didik dengan kompetensi Ngarti sebesar 0,886 dengan koefisien determinasi sebesar 0,778. Data tersebut menggambarkan bahwa variasi kompetensi peserta didik mampu dijelaskan oleh respon peserta didik sebesar $77,8 \%$, dan sisanya dipengaruhi oleh faktor lain, seperti penggunaan model pembelajaran $4 \mathrm{~N}$ yang mampu mempengaruhi kompetensi Ngarti sebesar 77,8\%.

Hasil penghitungan uji regresi untuk melihat pengaruh model pembelajaran $4 \mathrm{~N}$ terhadap kompetensi Ngrasa disajikan pada Tabel 18.

Tabel 18. Output Model Summary Uji Regresi Kompetensi Ngrasa

\begin{tabular}{cccc}
\hline Model & R & R Square & Adjusted R Square \\
\hline 1 & 0,770 & 0,592 & 0,579 \\
\hline
\end{tabular}

Korelasi antara respon peserta didik dengan kompetensi Ngrasa sebesar 0,770 dengan koefisien determinasi $\left(\mathrm{R}^{2}\right)$ sebesar 0,579. Tabel 18 juga menggambarkan bahwa perubahan kompetensi Ngrasa peserta didik dipengaruhi oleh veriabel dependen, yakni pembelajaran IPA berbasis model pembelajaran $4 \mathrm{~N}$ sebesar $57,9 \%$, dan sisanya dipengaruhi oleh faktor lain. Respon peserta didik menunjukkan hubungan yang signifikan dengan pembelajaran IPA berbasis model pembelajaran $4 \mathrm{~N}$ yang mampu mempengaruhi kompetensi Ngrasa sebesar 57,9\%.

Untuk mengetahui besarnya sumbangan variabel independen terhadap variabel dependen dapat dilihat pada hasil output model summary yang disajikan pada Tabel 18.

\section{Tabel 19. Output Model Summary Uji Regresi Kompetensi Nglakoni}

\begin{tabular}{cccc}
\hline Model & R & R Square & Adjusted R Square \\
\hline 1 & 0,929 & 0,863 & 0,858 \\
\hline
\end{tabular}

Korelasi antara respon peserta didik dengan kompetensi Nglakoni sebesar 0,929 dengan koefisien determinasi sebesar 0,858 . Tabel 19 juga mengilustrasikan bahwa perubahan kompetensi Nglakoni peserta didik dipengaruhi oleh variabel dependen yakni pembelajaran IPA berbasis model pembelajaran $4 \mathrm{~N}$ sebesar $85,8 \%$, dan sisanya dipengaruhi faktor lain. Selain itu juga diperoleh informasi mengenai hubungan yang signifikan antara respon peserta didik terhadap pembelajaran IPA berbasis model pembelajaran $4 \mathrm{~N}$ yang mampu mempengaruhi kompetensi Nglakoni sebesar 85,8\%.

\section{Respon Peserta didik terhadap Model Pem- belajaran dan LKS IPA Berbasis 4N}

Respon peserta didik terhadap model pembelajaran $4 \mathrm{~N}$ ini dengan skor maksimal sebesar 100 dan skor minimal sebesar 20. Sebanyak 32 peserta didik yang menjadi subyek uji coba lapangan operasional memberikan skor total sebesar 2.562, dengan rerata sebesar 80,06. Berdasarkan kategorisasi penilaian respon peserta didik terhadap model pembelajaran $4 \mathrm{~N}$ menunjukkan bahwa model pembelajaran $4 \mathrm{~N}$ yang dipraktekkan di dalam kelas uji coba lapangan operasional mendapatkan respon baik dari peserta didik.

Jumlah item untuk penilaian LKS IPA berbasis model pembelajaran $4 \mathrm{~N}$ sebanyak 15 butir. Oleh karena itu, skor maksimal yang bisa didapatkan sebesar 75 dan skor minimal sebesar 15. Skor total dari 32 peserta didik dalam uji coba lapangan operasional sebesar 1.869 dengan rerata sebesar 58,41 seperti yang disajikan pada Tabel 20. Sesuai dengan kategorisasi penilaian respon peserta didik terhadap LKS IPA berbasis model pembelajaran $4 \mathrm{~N}$ diperoleh hasil bahwa LKS IPA yang diujicobakan mendapatkan respon baik. 
Tabel 20. Respon Angket Peserta didik Terhadap Model Pembelajaran dan LKS IPA Berbasis Model Pembelajaran 4N dalam Uji Coba Lapangan Operasional

\begin{tabular}{cccc}
\hline Komponen & $\begin{array}{c}\text { Skor } \\
\text { Total }\end{array}$ & Rerata & Kategori \\
\hline Model Pembelajaran 4N & 2562 & 80.06 & Baik \\
LKS IPA berbasis 4N & 1869 & 58.41 & Baik \\
\hline
\end{tabular}

Respon peserta didik terhadap model pembelajaran $4 \mathrm{~N}$ dan LKS IPA berbasis model pembelajaran 4N disajikan pada Gambar 6

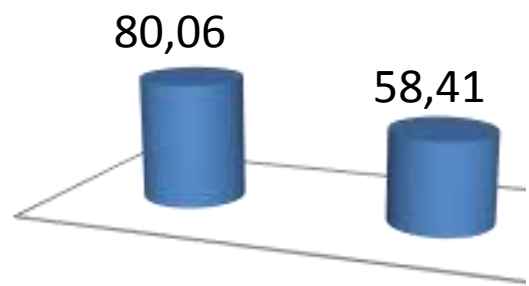

Gambar 6. Histogram Respon Peserta Didik pada Uji Coba Lapangan Operasional terhadap Model dan LKS IPA berbasis Model Pembelajaran $4 \mathrm{~N}$

\section{Ketuntasan Belajar Peserta Didik}

Standar skor kriteria ketuntasan minimal (KKM) SMP 3 Banguntapan untuk mata pelajaran sebesar 6,0. Besarnya angka didasarkan pada evaluasi yang menunjukkan bahwa peserta didik yang mendapat skor minimal 6,0 telah memiliki ketuntasan minimal dalam menguasai materi pembelajaran IPA. Ketuntasan klasikal tergambar ketika peserta didik yang mencapai skor tuntas sebanyak minimal $75 \%$ dari total peserta didik dalam kelas. Berdasarkan uji lapangan operasional diperoleh skor posttest peserta didik.

Tabel 21. Ketuntasan Peserta Didik

\begin{tabular}{ccc}
\hline No & Kategori & Jumlah Peserta didik \\
\hline 1 & Tuntas & 28 \\
2 & Tidak Tuntas & 4 \\
\hline
\end{tabular}

Skor yang diperoleh dihitung dengan menggunakan rumus persentase ketuntasan klasikal.

$$
N_{K}=\left(\frac{N_{A}}{N_{T}}\right) x 100 \%=\left(\frac{28}{32}\right) \times 100 \%=87,5 \%
$$

Berdasarkan hasil penghitungan diperoleh informasi bahwa jumlah peserta didik yang mencapai tuntas di kelas eksperimen minimal 75\%. Hasil ini menunjukkan bahwa ketuntasan belajar klasikal di kelas eksperimen telah tercapai.

\section{SIMPULAN DAN SARAN}

\section{Simpulan}

Konsep 4N Ki Hajar Dewantara, yakni (a) Neng mengandung nilai ketelitian, kecermatan, kehati-hatian, ketekunan, ketepatan dan masuk dalam tahap pembelajaran berupa observasi, (b) Ning mengandung nilai ketelitian, kecermatan, ketepatan dan masuk dalam tahap pembelajaran berupa konseptualisasi, (c) Nung mengandung nilai kecermatan, ketepatan, kebesaran hati, toleransi dan masuk dalam tahap pembelajaran pemahaman-pendalaman konsep, serta (d) Nang mengandung nilai kebesaran hati dan masuk dalam tahap pencapaian hasil belajar.

Kualitas panduan model pembelajaran IPA berbasis 4N yang dihasilkan berkualifikasi sangat baik, sehingga layak digunakan dalam pembelajaran IPA. Silabus dan RPP IPA berbasis $4 \mathrm{~N}$ berkualifikasi sangat baik, sehingga layak digunakan sebagai perangkat pembelajaran IPA. Untuk LKS IPA berbasis model pembelajaran $4 \mathrm{~N}$ dengan kualifikasi sangat baik, yang menunjukkan bahwa perangkat pembelajaran ini layak digunakan sebagai alat bantu pembelajaran IPA.

Pembelajaran IPA dengan model $4 \mathrm{~N}$ ini mampu mencapai pembelajaran fungsional. Kondisi ini dilihat dari pencapaian 3 kriteria pembelajaran fungsional, yaitu: (1) mampu meningkatkan kompetensi ngarti peserta didik SMP untuk mata pelajaran IPA dengan rata-rata skor untuk kelas eksperimen sebesar 77,68, sedangkan kelas kontrol sebesar 64,39. Berdasarkan uji t independent sample test diperoleh skor probabilitas sebesar 0,000 yang menunjukkan bahwa terdapat perbedaan signifikan antara kompetensi ngarti di kelas eksperimen dan di kelas kontrol. Berdasarkan uji regresi diperoleh informasi besarnya pengaruh model pembelajaran $4 \mathrm{~N}$ terhadap kompetensi ngarti sebesar $77,8 \%$. Besar pengaruh model pembelajaran $4 \mathrm{~N}$ terhadap kompetensi ngrasa sebesar 57,9\%; sedangkan untuk kompetensi nglakoni sebesar 85,8\%. (2) ketuntasan klasikal peserta didik dalam pembelajaran IPA berbasis $4 \mathrm{~N}$ mencapai sebesar $87,5 \%$. (3) respon peserta didik terhadap model pembelajaran dan LKS IPA berbasis $4 \mathrm{~N}$ dengan kualifikasi baik. Untuk itu model pembelajaran $4 \mathrm{~N}$ ini diterima oleh peserta didik sebagai model pembelajaran yang menyenangkan.

Pembelajaran IPA dengan menggunakan model $4 \mathrm{~N}$ yang dikembangkan dapat terlaksana dengan kategori sangat terlaksana berdasarkan hasil uji coba lapangan operasional. 


\section{Saran}

Berdasarkan hasil penelitian dapat disarankan: (1) model pembelajaran IPA berbasis $4 \mathrm{~N}$ diharapkan dapat diimplementasikan sebagai alternatif model pembelajaran oleh pendidik untuk membantu peserta didik dalam mempelajari mata pelajaran IPA. (2) panduan model pembelajaran IPA berbasis $4 \mathrm{~N}$ diharapkan dapat diimplementasikan oleh pendidik untuk pembelajaran di dalam kelas. (3) RPP dan LKS IPA berbasis $4 \mathrm{~N}$ yang dikembangkan dapat digunakan oleh pendidik dan siswa untuk mewujudkan pembelajaran IPA yang fungsional

\section{Daftar Pustaka}

Anwar, K. \& Harmi, H. (2011). Perencanaan sistem pembelajaran kurikulum tingkat satuan pendidikan (KTSP). Bandung: Alfabeta.

Aunurahman. (2010), Belajar dan pembelajaran. Alfabeta, Bandung.

Borg, W.R. \& Gall, M.D. (1983). Educational research: an introduction. $4^{\text {th }}$ Edition. New York: Longman Inc.

Bundu, P. (2006). Penilaian keterampilan proses dan sikap ilmiah dalam pembelajaran sains Sekolah Dasar. Jakarta: Depdiknas.

DePorter, B.; Reardon, M.; \& Singer-Nourie, S. (2001). Quantum teaching: mempraktikkan quantum learning di ruang-ruang kelas. (terjemahan Ary Nilan-Dary). Boston: Allyn and Bacon.

Dewantara, K.H. (1977). Pendidikan. Yogyakarta: Majelis Luhur Persatuan Taman Peserta didik.

Widoyoko, S.E.P. (2012). Teknik penyusunan instrumen penelitian. Yogyakarta: Pustaka Pelajar.

Ghozali, I. (2011). Aplikasi Analisis Multivariate dengan program IMB SPSS 19.
Semarang: Badan Penerbit Universitas Diponegoro.

Hamalik, O. (2005). Proses belajar mengajar. Jakarta: PT Bumi Aksara

Joyce, B,. \& Weil, M. (1996). Models of Teaching. USA: A Simon \& Schuster Company.

Riyanto, Y. (2010). Paradigma baru pembelajaran sebagai referensi bagi pendidik dalam implementasi pembelajaran yang efektif dan berkualitas. Jakarta: Kencana.

Setiawan, E. (2010). Kamus Besar Bahasa Indonesia Versi 1.1. [versi elektronik]. Diambil pada tanggal 30 September 2013.

Sharma, A. (2012). What are the functions of education towards individual, society, and country?. Artikel. Diambil pada tanggal 21 Maret 2012, dari http:/www.preservearticles.com2011022 44178/what-are-the-functions-ofeducation-towards-individual,-societyand-country.html

Sugiyono. (2010). Metode penelitian pendidikan. Bandung: Penerbit Alfabeta.

Suparno, Pl. (2007). Metodologi pembelajaran fisika; konstruktivistik dan menyenangkan. Yogyakarta: Universitas Sanata Dharma.

Tim Pengembang Ilmu Pendidikan FIP-UPI. (2007). Ilmu dan aplikasi pendidikan. Jakarta: Imtima.

Tim Puslitjaknov. (2008) .Metode Penelitian Pengembangan. Depdiknas.

Thut I.N, Adams, D. (2005). Pola-pola Pendidikan dalam Masyarakat Kontem-porer. Yogyakarta: Pustaka Pelajar. 